Faulty solar panel jeopardizes Mars mapping project

[WASHINGTON] A faulty solar panel on the US Mars Global Surveyor spacecraft has led mission managers to suspend normal operations, and may jeopardize their goal of mapping the entire planet at high resolution.

Project managers raised the craft's orbit to a safe altitude on 12 October after one of two electricity-producing panels moved unexpectedly while experiencing drag in the martian atmosphere.

Since arriving at Mars last month, the spacecraft has been repeatedly dipping into the atmosphere to lower and circularize its elliptical orbit, a technique known as 'aerobraking'. But on 6 October the atmospheric density suddenly doubled. The solar panel, which engineers had thought was stuck open at 20 degrees from its intended latched position, moved first to the latched position, then past it.

Engineers at the Jet Propulsion Laboratory in Pasadena, California, and Lockheed Martin Astronautics in Denver, Colorado, which built the spacecraft, will spend two weeks or more trying to duplicate the solar array's behaviour using a replica on the ground to try to understand the problem.

Mars Global Surveyor is meant to end up in a nearly circular orbit averaging $378 \mathrm{~km}$ above the surface of Mars. Mapping had been due to begin in March and to last for 687 days, or one full martian year. Even if no more aerobraking is allowed, it may be possible to use the spacecraft's fuel to lower its altitude, but it is unlikely that the optimum mapping orbit could then be achieved. Science instruments continue to collect data while engineers are studying the solar panel problem.

If the craft remains in an elliptical orbit, it will be too far from the surface of Mars for high-resolution imagery, so observations of the planet's southern hemisphere will suffer, according to Michael Malin of Malin Space Science Systems in San Diego, California, which built the spacecraft's camera system.

Some damage has already been done. The plan was for the craft to pass over the martian equator at the same time every day, two o'clock in the local afternoon. Due to the hiatus in aerobraking, that orbit is no longer possible, says Malin, so other options are being considered.

If crossing the equator shifts too much towards midday, the shadows become shorter, and the definition of surface features would be washed out in the photographs. Malin says a mid-morning equator crossing is preferable for imagery, but is not ideal for thermal measurements of the surface, which are better done in the afternoon after the planet has warmed up.

Tony Reic hhardt

\title{
Genome research strategy splits Japanese scientists
}

[TOKYO] Japanese government officials are said to be trying to resolve a dispute about strategy between researchers taking part in the Genome Frontier Programme, a project backed by the Science and Technology Agency (STA) and the Institute of Physical and Chemical Research (RIKEN).

The ¥4-billion (US\$33-million) project, due to start in October next year, had been intended to be based on new techniques that make use of full-length complementary DNAs (cDNAs) for DNA base sequencing, elucidating gene and protein function, and analysing protein structure. The use of full-length cDNA allows key parts of the clone to be targeted for sequencing, as well as direct production of proteins from the cloned cDNA.

But some leaders of Japan's human genome research who have been advising on the programme are said to oppose this strategy, and to be insisting that the programme be restricted to DNA sequencing.

"The formal description of the project is that it will involve both DNA sequencing and protein-related research, but this is very unlikely to happen," says a leading genome researcher at Kyoto University. "The protein-related research will probably have to be carried out under a different project."

The research strategy proposed by RIKEN was planned to combine three projects: sequencing a full-length cDNA using the latest automated high-speed DNA sequencer; producing a genetic 'encyclopaedia' of gene and protein functions; and analysing protein structure by using nuclear magnetic resonance (NMR) at the 'NMR Park' that the STA wanted to set up (see Nature 381, 815; 1996).

But many scientists now fear the RIKEN programme may become little more than an extension of a DNA sequencing project carried out at Japan Science and Technology Corporation, formerly the Japan Information Centre of Science and Technology.

"A national project like this should consider its accountability to the taxpayers," says
Akiyoshi Wada, former dean of science at Tokyo University and the director of Sagami Chemical Centre, a privately funded institute which has filed Japan's first applications for patents on human genes (see Nature $361,815 ; 1996)$. "DNA sequencing alone will not contribute to the understanding of gene function; only through protein-related research can we obtain patentable products for medical use and research."

A member of the Japanese Diet (parliament) is said to have intervened in the STA budget plan, introducing a requirement that the agency should carry out only DNA sequencing research, which he considers an "international trend", and postponing protein-related research as being "premature".

But one project leader at RIKEN claims that, if the proposed projects are abandoned, Japan will miss out on a chance to join the front rank of international genomics research. "DNA sequencing is already being carried out in Europe and the United States, and we are relatively behind in this field." People in Japan, he says, are reluctant to enter new areas in genetic research, which is still dominated by the 'traditionalists'.

But another prominent leader of Japanese genome research supports placing an emphasis on DNA sequencing, on the grounds that the Japanese effort in human genome research is not sufficiently advanced. "Although supporters of the protein-related research emphasize the need to compete internationally, that is only to attract funding from the Ministry of Finance," he says. "Realistically, such an unprecedented project should be considered as a potential project for the future."

Wada, who argued strongly for automated and high-speed DNA sequencing ten years ago, is bitter about where the Genome Frontier Programme may be heading. "My suggestion was ignored in Japan ten years ago, and this is the main reason why we are lagging behind other countries," he says. "We cannot be left behind again." Asako Saegusa

\section{Launc $h$ of Lunar Pros pector delayed}

[WASHINGTON] The launch of a low-budget US spacecraft mission to map the chemical composition and gravitational field of the Moon and search for evidence of ice has been delayed for the second time.

The \$63-million Lunar Prospector will now leave Earth no earlier than 5 January, due to delays in developing its new Athena 2 launch vehicle.

The launcher and spacecraft are built by
Lockheed Martin Corporation. Lunar Prospector's launch was originally scheduled for September, then November. If the date slips past February, it could compromise the mission's ability to meet all its scientific objectives, according to the principal investigator, Alan Binder of the Lunar Research Institute in Gilroy, California. The current plan is to complete the main mission before a lunar eclipse in July 1999. 